\title{
The View of the Experts on the Currency Depreciation of Cash Waqf Value
}

\author{
Rahmi Amalia ${ }^{1, \text { a }}$ \\ ${ }^{1}$ Study of Islamic Economics, Center of Religious and Cultural Studies, \\ Postgraduate School, Universitas Gadjah Mada \\ Jl. Teknika Utara, Pogung, Sleman, Yogyakarta, Indonesia 55281 \\ a rahmiamalia512@gmail.com
}

DOI: https://doi.org/10.22219/jes.v5i2.13762

\begin{tabular}{ll}
\hline & \multicolumn{1}{c}{ ABSTRACT } \\
\cline { 2 - 2 } Keywords: & This study aims to analyze the view of the experts on the currency \\
Waqf; Cash & depreciation of cash waqf value. This research was decriptive \\
Waqf; & qualitatif, the method of collecting data done by documentation and \\
Productive & an interview. The data analysis used was content analysis. The result \\
Waqf; Value of & $\begin{array}{l}\text { of this study found that the experts all agreed that the risk of } \\
\text { decreasing currency value will have an impact on the value of cash }\end{array}$ \\
& waqf.
\end{tabular}

Article Info:

Submitted: $15 / 07 / 2020$

Revised: 05/08/2020

Published: $30 / 08 / 2020$

How to cite: Amalia, R. (2020). The View of the Experts on the Currency Depreciation to Cash Waqf Value. Falah: Jurnal Ekonomi Syariah, 5(2), 99-110. doi. https://doi.org/ 10.22219/jes.v5i2.13762

\section{INTRODUCTION}

Waqf is part of the perpetual alms which is believed that the rewards of it would be given continuously throughout its ongoing utilization (Ariff \& Mohamad, 2017; Miah, 2019; Suhaimi, et, al., 2020; Mohamad \& Mohamad, 2020). Waqf has its own distinctive characteristics in comparison to other forms of philanthropy (Kahf \& Mohomed, 2017; 
Abdullah, 2017; Shaikh, et. al., 2017; Iman, et. al., 2017; Rizal, et. al., 2017). Two characteristics of waqf are the existence of immortality of the waqf (baqa 'al-ain) and the sustainability of the long-term benefits (dawam al-manfaat) (Abdullah, 2018; Jung, et. al., 2018; Abdullah, 2019; Abdullah, 2020; Hudaa \& Santosob, 2020). On the other word, (Kholil, 2011) stated that the main point that distinguishes waqf and alms in general is the transfer process of substance and the benefits in its management.

Cash waqf was already introduced by the Prophet in his prophecy era. However, the waqf objects that were generally used in the practice of waqf were still limited, only to immovable objects or fixed asset (Shaikh, et. al., 2017; Rosadi, et. al., 2018; Mustofa, et. al., 2020). Cash waqf was first known since the Imam Malik bin Anas became the first Imam who allowed the presence of Waqf money (Rohmaningtyas, 2017; Jalil, 2018). This practice had been applied by the ancient Romans, Mesopotamia, and Greece, who used gold and silver as their money standard in order to provide venture capital and fixed return value (Ahmad, 2015). According to the fatwa of Indonesia Ulema Council (MUI) cash waqf is a waqf which in its activities can be done by a person or a group of people or institutions whose waqf object is in the form of cash, based on the notion that money is securities asset (Majid, 2008).

Previous Islamic scholars, such as the scholars of the four schools (mazhab), have different or contesting views over the practice of cash waqf. But the majority of scholars have agreed that the money can be the object of waqf. Because money has met the characteristics as a waqf object and because there is consideration for the benefit of maslahat for mankind (Ibrahim, 2009).

According to Hanafi's opinion, cash waqf have to do with the conversion (istibdal) of the object of waqf to the immovable asset over the object being represented, so that its benefits were perpetual (Zahrah, 1971; Mohsin, et. al., 2016; Sakti, et. al., 2016; Ambrose, et. al., 2018). This view depend on the existance of fearness of inconsistency over the volatile value of the substance. therefore the money need to be converted into immovable objects (Rozalinda, 2015).

The current money used is fiat money that is set by the government decree (Mankiw, 2003). In Islamic economics, money is a medium of exchange, not a capital. On the other hand, in conventional economics money is considered as both: a medium of exchange and a capital (Karim, 2008). The recent government policy related to monetary policy was more dominated by conventional economic system, which takes referral to superpower country like the United States (US) Dollar as currency (Darwis, 2014).

The Figure 1 illustrates that the money value in developing countries (for example Indonesia) which uses a floating exchange rate system and the value of its currency is likely to continue to decline. The picture above shows in the last five years since 2013, the value of rupiah ranged between IDR 11,000,- to 11,700. However, by the end of 2017 , the value of the rupiah was weakened to around IDR 13,000 to 14,000 . 


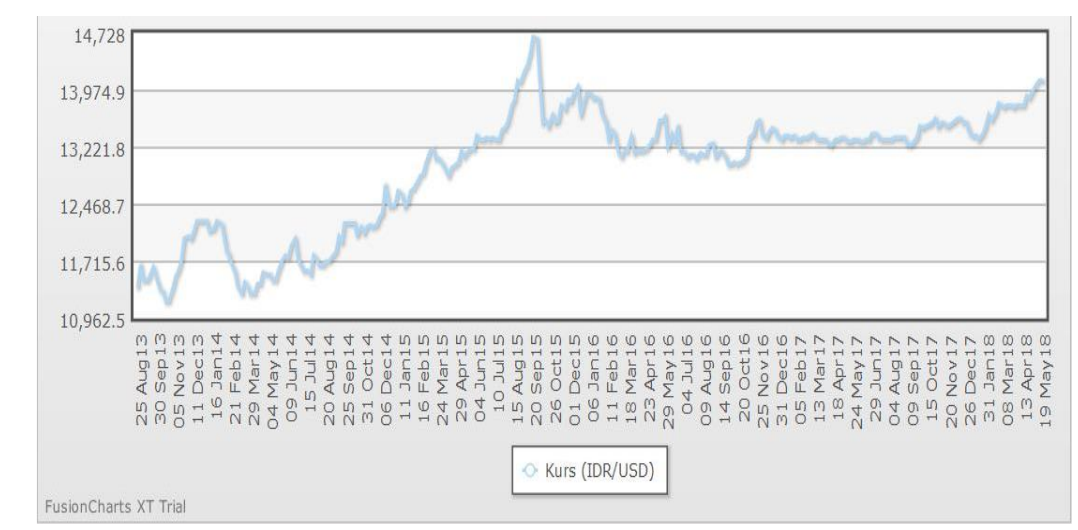

Source: https://kursdollar.net

Figure 1. The Indonesia Rupiah (IDR) exchange rate to US \$ Dollar

The condition of the global economy also proves that the type of money in modern times is highly vulnerable to depreciation especially under crisis situation (Williamson, 1998; De Paula, et. al., 2017). The large contribution of unmanaged inflation is the result of the creation from conventional system implementation policies which have a negative impact on the value of money (Pažický, 2018; Ffrench-Davis\& Griffith-Jones, 2019; Jin, Mendis \& Sutherland, 2019). The character that is formed by the enforcement of conventional economic system is that the value of money has a low resistance, because of inflation often causes the crisis that will lead to the decreasing value of money and it could happen continuously (Huber, 2016; Skidelsky, 2018; Cossiga, 2019; Fantacci, 2019).

On the inflation, Maqrizi stated that the inflation conditions can not be eliminated, caysed by declining supply in aggregate, or increasing demand in aggregate (Pangiuk, 2013). This condition occurring inflation period can not be prevented because it is a form of market mechanism (Karim, 2008).

Several research was conducted related to this topics. Ariff \& Mohamad (2017), stated that waqf is a form of wealth management which to process the accumulation, generation, purification, preservation and distribution of wealth, all to be conducted carefully in permissible ways. Furthermore, cash waqf can be an alternatif instrument to improve the economic walfare of society (Hasanah, 2011; Pusparini, 2016; Rohmaningtyas, 2017; Fuadi, 2018; Mohamad \& Mohamad, 2020). In line with this opinion, Ahmad (2015) stated that cash waqf is able to promote enterpreneurship in the world with interest free loans through waqf institutions.

Shaikh, Ismail, \& Shafiai, (2017) found that the institution of waqf can fill the gap as a social finance institution by providing intermediation services for effectively utilising perpetual social savings. Khademolhoseini (2008); Siswantoro, Rosdiana \& Fathurahman (2018), stated that waqf has a principle of perpetuity that makes it differ from a foundation, charity or ordinary donation fund as widely practiced in Western countries. According to Hasanah \& Hakim (2017), the a principle of perpetuity has a permanent and 
immutable nature can be applied to create a lasting urban forest that does not have the potential to be evicted.

Rosadi, et. al., (2018) found that the existence of waqf, not only in the individual obligations but also in social meaning in the context of collective obligations involving the property, the person creating a waqf, the manager of waqf, waqf users, and the legal act of waqf. On the other hand, Rusydiana (2018), stated that the development of cash waqf in Indonesia through the ISM framework can be classified into three criteria: first, the challenges faced in developing cash waqf. Second, the strategies or foundations needed in the cash waqf development framework. Third, the role of stakeholders and figures involved in managing waqf.

Dewi (2019), stated that to to secure cash waqf from depriciation of asset value caused by the decrease of cash money value, she proposed that asset should invest in accordance with sharia. Furthermore, Mustofa, Santoso \& Rosmalinda (2020), found that both Indonesia and Malaysia have been sufficiently rigid and representative.

However, those research was limited to a particular condition on the management of cash waqf and the role of the waqf institution as a social finance institution to develope economics walfare of the ummah. This study aims to do an indepth analyze on the views of the experts of the currency depreciation on cash waqf asset. The data collection was done by interviewing the waqf experts and analyze on the related literature about money waqf.

\section{RESEARCH METHOD}

This research was qualitative descriptive by conducting conceptual and empirical framework approach through critical analysis (Sugiyono, 2004). The conceptual approach was used to answer the question about how the impact of the decreasing currency value will affect the cash waqf assets. While the empirical approach was used to obtain data and evidence in the field about the views of experts regarding the decreasing currency value that will affect the waqf money assets.

The descriptive aspect was done to elaborate, describe, and explain thoroughly about the problem under the study, so that it can answer the problem formulation that exists in this research (Sangalang, 2017). This study conducts analysis by analayzing the information about cash waqf, seeking relationships from recognized literature sources, and finding results on the basis of data which will be analyzed and narrated, i.e analyzing and presenting the facts systematically so that it can be easier to understand and concluded. The data collection was done by interviewing the waqf experts and doing the study on the related literature about money waqf as listed in the table 1. 
Vol. 5 No. 2 (2020)

ISSN (print): 2502-3918| ISSN (online): 2502-7824

Table 1. List of Respondents

\begin{tabular}{ccl}
\hline No. & \multicolumn{1}{c}{ Name } & \multicolumn{1}{c}{ Role } \\
\hline 1 & M. Yasir Nasution & $\begin{array}{l}\text { Former Chairman of BWI SUMUT, Sharia } \\
\text { Supervisory Board of Bank Sumatera Utara } \\
\text { (SUMUT) Sharia }\end{array}$ \\
\hline 2 & Akmaluddin Syahputra & $\begin{array}{l}\text { Deputy Secretary at the Council of Ulama of } \\
\text { Indonesia (MUI, North Sumatera Province. }\end{array}$ \\
\hline 3 & Syafruddin Syam & Researcher of Productive Endowment \\
\hline 4 & H. Arso & $\begin{array}{l}\text { Vice Chairman of BWI in North Sumatera } \\
\text { Province \& Vice Chairman at the Council of } \\
\text { Ulama of Indonesia (MUI, North Sumatera } \\
\text { Province. }\end{array}$ \\
\hline
\end{tabular}

The data analysis technique used in this study was qualitative data analysis following three phases namely: data reduction, data display, and drawing a conclusion (Miles \& Huberman, 1992). Data reduction was done, after reading, studying, and reviewing all the sources, by summarizing the core of the materials. Subsequently abstraction was performed and finally the data interpretation conducted to find a result of the research.

\section{RESULT AND DISCUSSION}

Yasir Nasution, former chairman of BWI SUMUT as well as Sharia Supervisory Board of Sharia Business Unit of Bank Sumatera Utara, argues that the presence of cash waqf as a form of derivative from charity practice has been developed to provide greater benefits for the people.

However, this charity needs to clarify many detailed characteristics in order to create a better management. He explains some facts that commonly in its practice, the cash waqf assets are managed only for buying the fixed asset which could be productive or used for the social welfare. Furtehermore, he mentioned that this kind of practice was not a form of cash waqf but waqf through money. However, based on real case in the field, the management is less productive.

Further, Yasir describes some obstacles occurred caused by the lack of understanding among the waqf managers (Nadzir) on the cash endowments due to the very rare practice of this cash waqf. They usually only treat these assets of cash waqf as a deposit fund, which is unfortunate. The policy and regulations on the management of cash waqf have been established, but the assets of cash waqf are still idle. If the asset of cash waqf is only treated as a deposit fund, then this will be susceptible to the impact of impairment of money value. While the money stored remains with the same exact nominal, but its purchasing power will decrease due to inflation.

The second respondent is a researcher and practitioner of waqf, and acting as Deputy Secretary at the Council of Ulama of Indonesia, North Sumatera, Akmaluddin Syahputra He does not comment much on the cash waqf practices that performed at Sharia Financial Institutions which follows the government regulations. This is because he is not a direct managerial member at the Waqf Board of Indonesia and LKS-PWU. However, He argues that the current practice of cash waqf will inevitably face the risk of a state of 
continuous decline in value throughout the year. In response to the depreciation that could affect the money waqf assets, then the money asset will be more productive when it is used as a source of capital for the people with mudharabah-based investment agreement, or could be aimed as sharia stocks which have a broader management system. Meanwhile, its implementation must avoid the potential risks that can threaten the existence of capital derived from the cash waqf.

Another opinion from Syafruddin Syam, a researcher of productive endowment, considers that the decreasing in money value or the fluctuation of the value of money will obviously affect the cash waqf. The object of cash waqf is money, and the value-shaped object will move along with the movement of objects which become its benchmark. In the case of money, which is a value-shaped item, then waqf money will follow the benchmark condition of money within that country. In Indonesia, the movement of the value of money depends on the condition of the interest rate. Even if the management agency conducts economic activities according to the Sharia principle, but basically the condition of money value in the transaction remains the same as money in conventional economic institutions. Therefore, money will still experience depreciation in both types of economic systems.

In cash waqf, either the reduced value of money in nominal or intrinsic value could be a violation to the norm of waqf. However, since waqf in practice has put its justification to the aspect of ijtihad ulama, there is no direct mention that this case is a violation. It is just necessary to review the intent and purpose of waqf and generalize it as the benefit that goes on continuously and can be felt by society. Therefore, if there are future findings which can formulate on how to maintain the money value in cash waqf, then why should this idea be eliminated? This could be a part for the next regulation on cash waqf to grow and how to endow. It would need further discussions in order to formulate clear and better regulation for money management, so that the existing risks could be minimized.

Another respondent, H. Arso, vice chairman of Indonesia Waqf Board (BWI) in North Sumatra and role vice chairman of Indonesia Ulema Council (MUI) in North Sumatra, gave his opinion that Indonesia Waqf Board at a Nadzir waqf institution and also Indonesia Ulema Council (MUI) have not been focused on the influence of declining value of money among scholars in North Sumatera, Indonesia. Indonesia's main obstacle is that most of its Muslim people are not 'literate' about cash waqf instrument, hence, the government is still focusing on the socialization of cash waqf, despite its awareness that the depreciation of money value would lead to reducing the benefits. Therefore, cash waqf should be managed in a more productive way, so that its value is not reduced.

On the other hand, Syafruddin has mentions some ways to eliminate a money, not only by stealing or destroying the physical form, but it can also be done by letting the value dropped. While Mr. Arso has also acknowledged that recently, some waqf management institutions only receive waqf funds but do not manage them properly due to the constraints they face from various aspects. This will also affect the value of the unmanaged money. Money continues to depreciate because it is not functioning and the 
Vol. 5 No. 2 (2020)

ISSN (print): 2502-3918 | ISSN (online): 2502-7824

quality of its usefulness also decreases. However, waqf money management institutions are now becoming more familiar with managing endowments for certain assets to be productive.

The views of the expert of the decreasing value of currency to cash waqf asset can be seen in the Table 2 ,

Table 2. The Expert Views on the Decreasing Value of Currency at Cash Waqf Asset

\begin{tabular}{|c|c|c|c|}
\hline No. & Name & Role & Main Opinion \\
\hline 1 & Yasir Nasution & $\begin{array}{c}\text { Former Chairman of BWI } \\
\text { SUMUT, Sharia Supervisory } \\
\text { Board of Bank Sumatera Utara } \\
\text { Sharia }\end{array}$ & $\begin{array}{l}\text { In practice, the cash waqf assets are } \\
\text { managed only for buying the fixed asset } \\
\text { which could be productive or used for the } \\
\text { social welfare. Furtehermore, he mentioned } \\
\text { that this kind of practice was not a form of } \\
\text { cash waqf but waqf through money. }\end{array}$ \\
\hline 2 & $\begin{array}{l}\text { Akmaluddin } \\
\text { Syahputra }\end{array}$ & $\begin{array}{l}\text { Deputy Secretary at the } \\
\text { Council of Ulama of Indonesia } \\
\text { (MUI, North Sumatera } \\
\text { Province. }\end{array}$ & $\begin{array}{l}\text { The current practice of cash waqf will } \\
\text { inevitably face the risk of a state of } \\
\text { continuous decline in value throughout the } \\
\text { year. In response to the depreciation that } \\
\text { could affect the money waqf assets, then } \\
\text { asset will be more productive when it is } \\
\text { used as a source of capital for the people } \\
\text { with mudharabah-based investment } \\
\text { agreement, or could be aimed as sharia } \\
\text { stocks which have a broader management } \\
\text { system. }\end{array}$ \\
\hline 3 & $\begin{array}{c}\text { Syafruddin } \\
\text { Syam }\end{array}$ & Researcher & $\begin{array}{l}\text { In Indonesia, the movement of the value of } \\
\text { money depends on the condition of the } \\
\text { interest rate. Even if the management } \\
\text { agency conducts economic activities } \\
\text { according to the Sharia principle, but } \\
\text { basically the condition of money value in } \\
\text { the transaction remains the same as money } \\
\text { in conventional economic institutions. } \\
\text { Therefore, money will still experience } \\
\text { depreciation in both types of economic } \\
\text { systems. }\end{array}$ \\
\hline 4 & H. Arso & $\begin{array}{l}\text { Vice Chairman of BWI in } \\
\text { North Sumatera Province \& } \\
\text { Vice Chairman at the Council } \\
\text { of Ulama of Indonesia (MUI, } \\
\text { North Sumatera Province. }\end{array}$ & $\begin{array}{l}\text { Some waqf management institutions only } \\
\text { receive waqf funds but do not manage them } \\
\text { properly due to the constraints they face } \\
\text { from various aspects. This will also affect } \\
\text { the value of the unmanaged money. Money } \\
\text { continues to depreciate because it is not } \\
\text { functioning and the quality of its usefulness } \\
\text { also decreases. }\end{array}$ \\
\hline
\end{tabular}

Based on the views of experts of cash waqf, the practice of managing cash waqf requires professionalism in its management. Regulations of waqf government have been well established to meet the demands of professionalism. The established regulation has 
appointed the authorities to be given the trust in the management of money waqf and assets of cash waqf. The related parties are the Indonesia Waqf Board (BWI) as the Nadzir of endowments and the Shariah Financial Institutions of Waqf Money Management (LKS-PWU) and Sharia Banks as those who are expected to actively manage money to be collected and managed professionally.

The indirect impact of the conventional system on money will also be experienced by LKS-PWU which is responsible for managing the money waqf assets. If the value of money is continuously allowed to decline and vulnerable to the crisis, then the usefulness of the benefits will also decrease. On the other hand, nowadays cash waqf has been known publicly, where wakif can endow his money in the period desired by the wakif. It is well known that cash waqf can be an alternatif instrument to improve the economic walfare of society as stated by Hasanah (2011); Ahmad (2015); Pusparini (2016); Rohmaningtyas (2017); Ariff \& Mohamad (2017); Shaikh, Ismail, \& Shafiai (2017); Fuadi (2018); and Mohamad \& Mohamad (2020). Even Mustofa, Santoso \& Rosmalinda (2020) found that Indonesia have been sufficiently rigid and representative.

Therefore, if the condition of money stability in value is not anticipated from the beginning, then the money waqf assets provided by the wakif could potentially continue to diminish following the condition of the money. This is in contrast to the characteristics of a waqf which requires permanency or eternal condition. As has been said before, the waqf of money relies in its purchasing value. Therefore, if a wakif endows his money within a certain period, then there is a possibility that his waqf will be reduced because of the condition from the decrease in value of money. Therefore, the stability of the value of money could greatly affect the condition and also the management of money waqf assets. For this decreasing value, Dewi (2019) stated that to secure cash waqf from depriciation of asset value caused by the decrease of cash money value, she proposed that asset should invest in accordance with sharia, Investments outside the sharia bank must be insured in sharia insurance.

On the other hand, Nazhir's expertise in managing and developing the waqf properties must being a concern in order to achieve the purpose, function and designation of the waqf properties. This is in line with Rosadi, et. al., (2018), that the existence of waqf, not only in the individual obligations but also in social meaning in the context of collective obligations involving the property, the person creating a waqf, the manager of waqf, waqf users, and the legal act of waqf.

Rusydiana (2018) added that the development of cash waqf in Indonesia through the ISM framework can be classified into three criteria: first, the challenges faced in developing cash waqf. Second, the strategies or foundations needed in the cash waqf development framework. Third, the role of stakeholders and figures involved in managing waqf. 
Vol. 5 No. 2 (2020)

ISSN (print): 2502-3918 | ISSN (online): 2502-7824

The current cash waqf practices will experience the risk of impairment of money due to different economic conditions in the past, this is inline with as stated by Kahf, M., \& Mohomed (2017); Gürsoy (2018).

The risk of the decreasing currency value is a risk which money could experience as long as it does not apply to a standard on more stable objects, because money does not store its value on its physicality. From this discourse, Rafiqi (2018) recommend gold and silver as the standard of the value for cash waqf because of its stablilty as stated by Noviyanti (2017). Therefore, without a stable standard on its value, there is a case where money continues to grow in nominal terms but could keep depreciating in terms of its value. This condition is often perceived in the endowments of money used as capital investment.

\section{CONCLUSION}

Based on the discussion that has been reviewed, it can be concluded that the experts all agreed that the risk of decreasing currency value will have an impact on the characteristics of waqf (in terms of object permanence and long-term benefits). Especially on the risk of decreasing currency value will affect the eternal/permanency value of waqf assets.

However, future research may add wider scope of experts from various backgorund of the study to find the more ideal model of the research and more realiable and valid result.

\section{REFERENCES}

Abd Jalil, M. (2018). Information Disclosure And Waqif Commitment: The Role of Trust As Mediator And Communication As Moderator (Doctoral dissertation, Universiti Sains Malaysia). Retrieved from http://ethesis.usm.my/jspui/handle/123456789/7817

Ahmad, M. (2015). Cash waqf: Historical evolution, nature and role as an alternative to riba-based financing for the grass root. Journal of Islamic Finance, 4(1), 63-74. Retrieved from https://platform.almanhal.com/Files/2/84764

Ambrose, A. H. A. A., Hassan, M. A. G., \& Hanafi, H. (2018). A proposed model for waqf financing public goods and mixed public goods in Malaysia. International Journal of Islamic and Middle Eastern Finance and Management. 11(3), 395-415. https://doi.org/10.1108/IMEFM-01-2017-0001

Ariff, M., \& Mohamad, S. (2017). Issues in waqf and zakat management. In Islamic Wealth Management. Edward Elgar Publishing. https://doi.org/10.4018/978-17998-1245-6.ch012

Ariffin, N. M., Archer, S., \& Karim, R. A. A. (2009). Risks in Islamic banks: Evidence from empirical research. Journal of Banking Regulation, 10(2), 153-163. Retrieved from https://link.springer.com/article/10.1057/jbr.2008.27

Cossiga, G. A. (2019). The Economy of Sustainability: Some Consequences on the Economic Theory. Theoretical Economics Letters, 9(8), 3034-3064. https://doi.org/10.4236/tel.2019.98187 
De Paula, L. F., Fritz, B., \& Prates, D. M. (2017). Keynes at the periphery: Currency hierarchy and challenges for economic policy in emerging economies. Journal of Post Keynesian Economics, 40(2), 183-202. https://doi.org/10.1080/01603477.2016.1252267

Dewi, O. E. R. (2019). The problem of securing cash waqf to anticipate the decline in asset value (Doctoral dissertation, UIN Walisongo). Retrievede from http://eprints.walisongo.ac.id/10711/

Fantacci, L. (2019). Cryptocurrencies and the Denationalization of Money. International Journal of Political Economy, 48(2), 105-126. https://doi.org/10.1080/08911916.2019.1624319

Ffrench-Davis, R., \& Griffith-Jones, S. (2019). Financial Globalization and Its Implications for Development. In The Palgrave Handbook of Development Economics (pp. 697-726). Palgrave Macmillan, Cham. Retrievede from https://link.springer.com/chapter/10.1007/978-3-030-14000-7_20

Fuadi, N. F. Z. (2018). Wakaf Sebagai Instrumen Ekonomi Pembangunan Islam. Economica: Jurnal Ekonomi Islam, 9(1), 151-177. https://doi.org/10.21580/economica.2018.9.1.2711

Gürsoy, Ç. (2018). The Financial Analysis of the Ottoman Cash Waqfs. In Global Approaches in Financial Economics, Banking, and Finance (pp. 389-413). Springer, Cham. Retrieved from https://link.springer.com/chapter/10.1007/978-3319-78494-6_19

Hasanah, I., \& Hakim, R. (2017). Pelestarian Hutan Kota Melalui Optimalisasi Wakaf Tunai. Research Report. Retrieved from http://researchreport.umm.ac.id/index.php/research-report/article/view/1010

Hasanah, U. (2011). Cash Waqf and People Economic Empowerment in Indonesia. Ekonomi Dan Keuangan Indonesia, 59(2), 215-232. Retrieved from https://www.lpem.org/repec/lpe/efijn1/201110.pdf

Huber, J. (2016). Sovereign money: Beyond reserve banking. Springer.

Ibrahim, I. M. (2014). Kaidah Fikih Dalam Mengatasi Transaksi yang Mengalami Inflasi. Economic: Jurnal Ekonomi dan Hukum Islam, 4(1), 1-16. Retrieved from http://ejournal.kopertais4.or.id/tapalkuda/index.php/economic/article/view/780

Ibrahim, M. A. (2009). Waqf al-Nuqud (Wakaf Uang) dalam Perspektif Hukum Islam. Al-Awqaf: Jurnal Wakaf dan Ekonomi Islam, 2(2), 1-12.

Jin, E., Mendis, G. P., \& Sutherland, J. W. (2019). Integrated sustainability assessment for a bioenergy system: A system dynamics model of switchgrass for cellulosic ethanol production in the US midwest. Journal of Cleaner Production, 234, 503520. https://doi.org/10.1016/j.jclepro.2019.06.205

Kahf, M., \& Mohomed, A. N. (2017). Cash Waqf: An Innovative Instrument of Personal Finance In Islamic Banking. Journal of Islamic Economics, Banking, and Finance, 13(3), 13-29. Retrieved from https://ibtra.com/pdf/journal/v13_n3_article1.pdf

Karim, A. (2008). Ekonomi Makro Islami. Jakarta: Rajawali Press.

Karim, A. A., \& Sahroni, O. (2015). Maqashid Bisnis Dan Keuangan Islam: Sintesis Fikih Dan Ekonomi. Jakarta: Rajawali Press.

Khademolhoseini, M. (2008). Cash-Waqf: A New Financial Instrument For Financing Issues: An Analysis Of Structure And Islamic Justification Of Its Commercialization. Imam Sadiq University. Retrieved from https://www.semanticscholar.org/paper/CASH-WAQF-A-NEW-FINANCIAL- 
Vol. 5 No. 2 (2020)

ISSN (print): 2502-3918 | ISSN (online): 2502-7824

INSTRUMENT-FOR-FINANCING-

Khademolhoseini/ffa4deafead1e41438bbccccb8370381302fae04?p2df

Mankiw, N. G. (2003). Teori Makroekonomi. Edisi 5. Jakarta: Erlangga.

Mohamad, S., \& Mohamad, M. A. (2020). Islamic Wealth Management and Issues in Waqf Management in Malaysia. In Challenges and Impacts of Religious Endowments on Global Economics and Finance (pp. 254-269). IGI Global. https://doi.org/10.4337/9781786439390

Mohsin, M. I. A., Dafterdar, H., Cizakca, M., Alhabshi, S. O., Razak, S. H. A., Sadr, S. K., \& Obaidullah, M. (2016). Financing the development of old Waqf properties. New York: Palgrave Macmillan. Retrieved from https://link.springer.com/book/10.1057\%2F978-1-137-58128-0

Mustofa, I., Santoso, D., \& Rosmalinda, U. (2020). The Implementation of The Regulation of Cash Waqf Management In Higher Educational Institution In Indonesia and Malaysia (A Study Of Legal System Theory). Humanities \& Social Sciences Reviews, 8(4), 69-77. https://doi.org/10.18510/hssr.2020.848

Noviyanti, R. (2017). Dinar dan Dirham Sebagai Alternatif Mata Uang: Sebuah Tinjauan Literatur. Falah: Jurnal Ekonomi Syariah, 2(2), 177-188. https://doi.org/10.22219/jes.v2i2.5104

Pangiuk, A. (2013). Inflasi pada Fenomena Sosial Ekonomi: Menurut Al-Maqrizi. Kontekstualita: Jurnal Penelitian Sosial Keagamaan, 28(1), 220-237. Retrieved from https://www.neliti.com/publications/146342/inflasi-pada-fenomena-sosialekonomi-pandangan-al-maqrizi

Pažický, M. (2018). The consequences of unconventional monetary policy in euro area in times of monetary easing. Oeconomia Copernicana, 9(4), 581-615. Retrieved from https://www.ceeol.com/search/article-detail?id=778217

Pusparini, M. D. (2016). Konsep Wakaf Tunai Dalam Ekonomi Islam: Studi Pemikiran Abdul Mannan. Falah: Jurnal Ekonomi Syariah, 1(1), 14-28. https://doi.org/10.22219/jes.v1i1.2692

Rafiqi, Y. (2018). The Problem of Perpetuity in Cash Waqf. International Journal of Nusantara Islam, 6(1), 10-19. https://doi.org/10.15575/ijni.v6i1.1321

Rohmaningtyas, N. (2017). The Significance Of Waqf In Historical And Teoritical Studies. Journal of Islamic Economics Science, 1(1), 39-55. Retrieved from https://e-journal.unair.ac.id/JIES/article/viewFile/10628/5996

Rosadi, A., Effendi, D., \& Busro, B. (2018). The Development of Waqf Management Throught Waqf Act in Indonesia (Note on Republic of Indonesia Act Number 41 of 2004 regarding Waqf). MADANIA: Jurnal Kajian Keislaman, 22(1), 1-18. http://dx.doi.org/10.29300/madania.v22i1.881

Rozalinda. (2015). Manajemen Wakaf Produktif. Jakarta: Rajawali Press.

Rusydiana, A. (2018). Aplikasi Interpretive structural modeling untuk strategi pengembangan wakaf tunai di Indonesia. Jurnal Ekonomi dan Bisnis Islam (JEBIS), 4(1), 1-17. Retrieved from e-journal.unair.ac.id

Sakti, M. R. P., Thaker, H. B. M. T., Qoyum, A., \& Qizam, I. (2016). Determinants of cash Waqf contribution in Klang Valley and Selangor: a SEM approach. Journal of Islamic Monetary Economics and Finance, 2(1), 111-144. https://doi.org/10.21098/jimf.v2i1.593

Shaikh, S. A., Ismail, A. G., \& Shafiai, M. H. M. (2017). Application of waqf for social and development finance. ISRA International Journal of Islamic Finance, 9(1), 514. https://doi.org/10.1108/IJIF-07-2017-002 
Siswantoro, D., Rosdiana, H., \& Fathurahman, H. (2018). Reconstructing accountability of the cash waqf (endowment) institution in Indonesia. Managerial Finance. 44(5), 624-644. https://doi.org/10.1108/MF-05-2017-0188

Skidelsky, R. (2018). Money and Government: A Challenge to Mainstream Economics. Penguin UK.

Sugiyono. (2004). Metode Penelitian Bisnis. CV Alfabeta, Bandung.

Williamson, J. (1998). Crawling bands or monitoring bands: How to manage exchange rates in a world of capital mobility. International Finance, 1(1), 59-79. https://doi.org/10.1111/1468-2362.00004

Wulandari, S., Effendi, J., \& Saptono, I. T. (2019). Pemilihan Nazhir Dalam Optimalisasi Pengelolaan Wakaf Uang. Jurnal Aplikasi Bisnis dan Manajemen (JABM), 5(2), 295. https://doi.org/10.17358/jabm.5.2.295

Zahrah, M. A. (1971). Muhadharat Fi al-Auqaf. Beirut: Dar al-Fikr. 